Naskah

\title{
Spons dari Tepung Glukomanan dengan Penambahan Charcoal
}

\author{
Novita $^{1}$, Nur Rahtiwi Anjarni ${ }^{1}$, dan Fadilah ${ }^{2, *}$ \\ ${ }^{1}$ Program Studi DIII Teknik Kimia, Fakultas Teknik, Universitas Sebelas Maret, Jl. Ir. Sutami 36 A \\ Surakarta 57126 \\ 2Prodi Teknik Kimia, Fakultas Teknik, Universitas Sebelas Maret, Jl. Ir. Sutami 36 A Surakarta 57126 \\ E-mail: fadilah@staff.uns.ac.id (*Corresponding author)
}

\begin{abstract}
A sponge was made with a basic ingredient of glucomannan with the addition of charcoal. In this experiment, the effect of two types of alkaline solution i.e., $\mathrm{Na}_{2} \mathrm{CO}_{3}$ and $\mathrm{NaOH}$, either the size and the amount of charcoal, were studied on the sponge's characteristics. The sponge was made by dissolving glucomannan flour in water. This step was followed by mixing the solution with Sodium Laureth Sulfate (SLS) and charcoal. The alkaline solution was added to form a wet gel. The dry sponge was obtained after thawing and sun drying. The sponge's characterization was done by observing the foam cavity using a camera microscope and analyzing water absorption, sponge expansion, and iodine adsorption. The sponge has cavities with a size between $0.1 \mathrm{~mm}$ to $0.25 \mathrm{~mm}$. Sponges with water absorption and high expansion were obtained by adding $\mathrm{NaOH}$ solution, one gram of charcoal and the size of charcoal $-50+60$ mesh. Sponge produced using $\mathrm{Na}_{2} \mathrm{CO}_{3}$ with 0.5 gram charcoal with size $60+70$ mesh has a high diameter cavity and a high adsorbed iodine value.
\end{abstract}

Keywords: glucomannan sponge, alkaline solution, charcoal

EQUILIBRIUM Volume 3 No.2 December 2019

Online at http://equilibrium.ft.uns.ac.id 


\section{Pendahuluan}

Spons (busa padat) merupakan suatu padatan seluler, yang diperoleh saat multi sel dengan batas atau permukaan padat terkemas bersama dalam satu ruang. Kita dapat menemui banyak spons dalam kehidupan sehari-hari seperti kayu, gabus, dan tulang hewan. Spons buatan manusia banyak ditemui semisal bahan pembungkus, bahan isian dalam mobil dan pesawat, serta bahan makanan kita sehari-hari seperti roti.

Sifat spons tergantung dari dua parameter. Parameter pertama dari spons adalah yang menggambarkan bahan dari dinding spons tersebut. Spons dari polimer bersifat kaku sedangkan yang berbahan dasar elastomer bersifat lebih fleksibel. Parameter kedua menggambarkan struktur geometri busa. Termasuk di dalamnya adalah kerapatan relatif, ukuran sel, bentuk sel dan cara zat padat didistribusikan antara tepi sel dan interface [1].

Spons dapat dibuat dari material polimer. Busa sintetis yang digunakan dalam pengepakan dan isolasi adalah polistirena, dan yang dipergunakan dalam mebel pada umumnya adalah poliuretan yang dibuat dari campuran poliol, toluena diisosianat, kalsium karbonat, air, melalmin dan pewarna [2]

Sebagai alternatif polimer sintetis, dikembangkan spons dengan bahan polimer alam. Spons polisakarida yang diproduksi dipergunakan sebagai pembalut luka, media replikasi kultur sel, dan bahan penjerap (adsorben). Busa polisakarida telah banyak dikembangkan dan menggunakan berbagai sumber polisakarida misalnya adalah alginat, kitosan, hyaluronat dan pektin [3]. Salah satu penggunaan spons polisakarida sebagai penjerap adalah busa konjak yang dipergunakan untuk membersihkan muka. Dalam fungsinya maka spons konjak diperuntukkan sebagai adsorben senyawa yang mengotori wajah.

Spons dari glukomanan merupakan suatu aerogel, suatu gel dengan bahan terdispersi berupa gas. Proses pembuatan aerogel dapat dimulai dari pembuatan hydrogel. Air yang terdistribusi di dalam hydrogel selanjutnya digantikan dengan etanol, (sovent exchange). Pelarut etanol selanjutnya diuapkan sehingga diperoleh aerogel. Surfaktan mungkin dimasukkan sebagai bahan pembantu terbentuknya rongga. Senyawa seperti Sodium laureth sulfate (SLS) dipergunakan dalam pembentukan busa polisakarida [1][2].

Gel glukomanan dapat diperoleh dengan penambahan alkali pada larutan glukomanan dan disertai dengan pemanasan. Larutan glukomanan dapat menghasilkan gel yang tidak larut dalam air, termal ireversibel gel dalam kondisi basa [5]. Proses pembentukan gel ditengarai akibat terjadinya deasetilasi yang berlanjut dengan agregasi molekul-molekul glukomanan.

Peningkatan sifat adsorben dilakukan dengan menambahkan charcoal. Dalam penelitian ini dipelajari pengaruh penambahan charcoal dalam pembuatan spons berbahan dasar glukomanan.

\section{Metode}

\subsection{Bahan}

Tepung porang diperoleh dari pedagang lokal di Jawa Barat. Akuades diperoleh dari Sub Laboratorium Kimia, Universitas Sebelas Maret. Etanol 96\%, Sodium Laureth Sulfate (SLS) dan Natrium Hidroksida $(\mathrm{NaOH})$ Natrium Karbonat $\left(\mathrm{Na}_{2} \mathrm{CO}_{3}\right)$ dan arang (charcoal) diperoleh dari toko lokal di Solo Jawa Tengah.

\subsection{Prosedur}

Pembuatan spons dilakukan dengan cara yang mengacu pada metode yang dilakukan oleh Triyanto (2018). Sejumlah $5 \mathrm{~g}$ tepung porang dilarutkan dalam $200 \mathrm{~mL}$ akuades dengan cara diaduk dengan kecepatan putar $1000 \mathrm{rpm}$ dengan waktu pengadukan selama 60 menit. Ke dalam larutan ditambahkan sodium laureth sulfate (SLS), bubuk charcoal dengan perbandingan 5:0,750:1 (g/g/g). Sejumlah $20 \mathrm{~mL}$ larutan basa ditambahkan juga ke dalam larutan dan selanjutnya dilakukan pengadukan sehingga terbentuk busa. Busa basah didiamkan selama 12 jam sebelum direndam dengan etanol 96\% selama 24 jam. Busa dikeluarkan dari cetakan dan dipanaskan di dalam oven selama 90 menit pada suhu $100{ }^{\circ}$ C. Pengeluaran air dari spons basah dilakukan dengan metode freezing-thawing sedua kali. Terakhir spons dikeringkan dengan sinar matahari.

Pada penelitian ini dilakukan penelitian pendahuan yang bertujuan untuk mengetahui pengaruh perendaman dengan etanol terhadap spons yang dihasilkan. Pengamatan karakteristik spons dilakukan terhadap spons dengan larutan alkali yang berbeda, yaitu larutan $\mathrm{NaOH}$ dan larutan $\mathrm{Na}_{2} \mathrm{CO}_{3}$, pada jumlah dan ukuran charcoal yang berbeda. Jumlah charcoal yang ditambahkan adalah 0,5 dan 1 gram dengan ukuran charcoal $\quad-50+60$ mesh dan $-60+70$ mesh.

\subsection{Karakterisasi spons.}

(1) Pengamatan terhadap rongga spons.

Dilakukan dengan melihat rongga menggunakan mikroskop kamera Dinolite.

(2) Daya serap air, 
dilakukan dengan mencelup spons kering ke dalam air panas yang dilanjutkan dengan meniriskan air dari spons basah. Daya serap air dihitung sebagai banyaknya massa air yang terserap dibandingkan terhadap massa bahan kering.

(3) Daya ekspansi spon basah

dilakukan dengan mengukur penambahan panjang spons terhadap ukuran panjang mula-mula.

(4) Nilai iod teradsorpsi

Daya serap terhadap iodin adalah jumlah miligram iodin yang diadsorbsi oleh satu gram spons kering.

\section{Hasil dan Pembahasan}

\subsection{Pecobaan pendahuluan.}

Pada penelitian ini, percobaan pendahuluan dilakukan untuk mengetahui pengaruh langkah perendaman spons dengan ethanol 96\% terhadap spons yang dihasilkan.

\subsubsection{Pembuatan Spons Glukomannan tanpa Charcoal dan tanpa Perendaman Etanol}

Dilihat dari segi fisik, spons glukomannan menggunakan alkali $\mathrm{Na}_{2} \mathrm{CO}_{3}$ tidak dapat membentuk rongga dan tidak dapat kering. Tekstur yang dihasilkan dengan menggunakan alkali $\mathrm{Na}_{2} \mathrm{CO}_{3}$ kenyal dan tidak rata. Sedangkan spons glukomanan menggunakan alkali $\mathrm{NaOH}$ dapat terbentuk spons kering, tetapi dengan bagian dalam dari spons masih basah, selain itu spons kering mengalami penyusutan. Hasil pembuatan spons dengan tanpa perendaman etanol dapat dilihat pada Gambar 1.

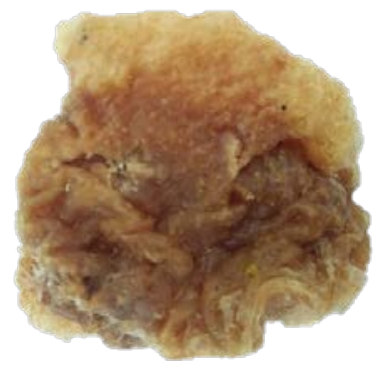

A

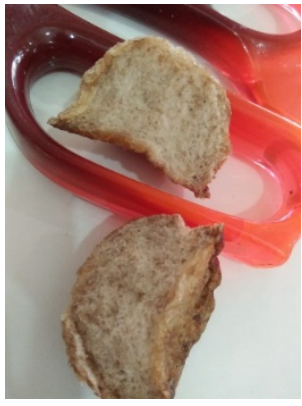

B

Gambar 1. Spons yang dihasilkan dengan proses tanpa perendaman menggunakan etanol A. menggunakan larutan $\mathrm{Na}_{2} \mathrm{CO}_{3}$. B. menggunakan larutan $\mathrm{NaOH}$.

\subsubsection{Pembuatan Spons Glukomannan tanpa Charcoal dengan Perendaman Etanol}

Dilihat dari segi fisik, spons glukomannan menggunakan alkali $\mathrm{Na}_{2} \mathrm{CO}_{3}$ tidak dapat terbentuk spons kering, bertekstur kenyal dan tidak membentuk rongga. Sedangkan spons glukomanan menggunakan alkali $\mathrm{NaOH}$ dapat terbentuk spons kering yang berongga. Gambar 2 menunjukkan spons yang dibuat dengan proses perendaman etanol.

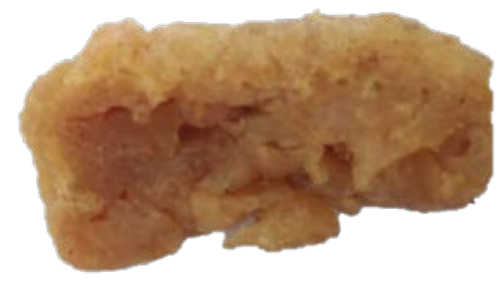

A

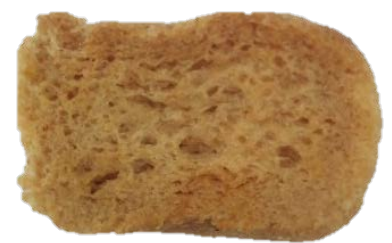

$\mathrm{B}$

Gambar 2. Spons yang dihasilkan dengan proses perendaman etanol. A. menggunakan larutan $\mathrm{Na}_{2} \mathrm{CO}_{3}$. B. menggunakan larutan $\mathrm{NaOH}$. 


\subsubsection{Pembuatan Spons Glukomannan dengan penambahan Charcoal tanpa Perendaman Etanol.}

Dilihat dari segi fisik, spons glukomannan yang dibuat dengan menggunakan alkali $\mathrm{Na}_{2} \mathrm{CO}_{3}$, tanpa perendalam etanol dan dengan penambahan charcoal dapat membentuk spons kering. Demikian juga spons glukomanan yang dibuat dengan menggunakan alkali $\mathrm{NaOH}$, tanpa perendalam etanol dan dengan penambahan charcoal dapat membentuk spons kering.

Tekstur yang dihasilkan dengan menggunakan alkali $\mathrm{Na}_{2} \mathrm{CO}_{3}$ lebih lunak dibandingkan yang menggunakan alkali $\mathrm{NaOH}$. Pada spons dengan $\mathrm{Na}_{2} \mathrm{CO}_{3}$ charcoal yang ditambahkan terlihat tidak menyatu dengan bagan glukomanan. Tekstur yang dihasilkan dengan menggunakan alkali $\mathrm{NaOH}$ lebih keras dibandingkan yang menggunakan alkali $\mathrm{Na}_{2} \mathrm{CO}_{3}$. Charcoal yang ditambahkan pada spons glukomannan dengan alkali $\mathrm{NaOH}$ dapat menyatu. Spons yang dihasilkan dengan penambahan charcoal tapi tidak direndam dalam etanol dapat dilihat pada Gambar 3.

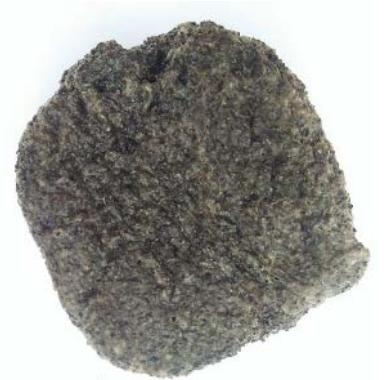

A

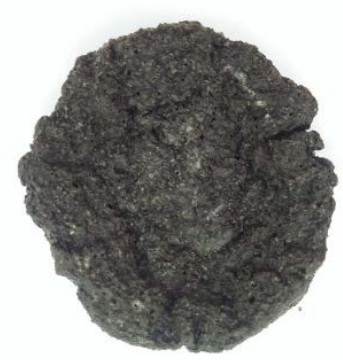

B

Gambar 3. Spons yang dihasilkan dengan penambahan charcoal tanpa proses perendaman etanol. A. menggunakan larutan $\mathrm{Na} 2 \mathrm{CO} 3$. B. menggunakan larutan $\mathrm{NaOH}$

\subsubsection{Pembuatan Spons Glukomannan dengan Penambahan Charcoal serta Perendaman Etanol.}

Dilihat dari segi fisik, spons glukomannan dengan penambahan charcoal serta perendalam etanol baik menggunakan alkali $\mathrm{Na}_{2} \mathrm{CO}_{3}$ maupun alkali $\mathrm{NaOH}$ dapat terbentuk spons kering. Tekstur yang dihasilkan dengan menggunakan alkali $\mathrm{Na}_{2} \mathrm{CO}_{3}$ lebih lunak dibandingkan yang menggunakan alkali $\mathrm{NaOH}$. Charcoal yang ditambahkan pada kedua jenis spons glukomannan dengan dapat menyatu. Gambar 4 menunjukkan kedua spons yang terbentuk.

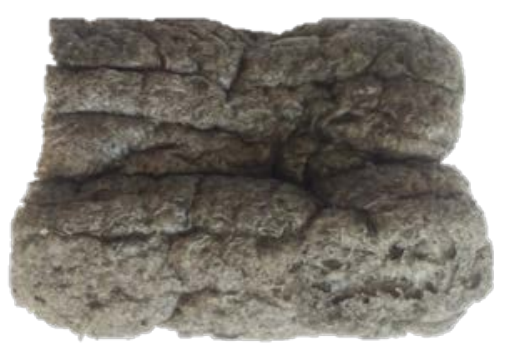

A

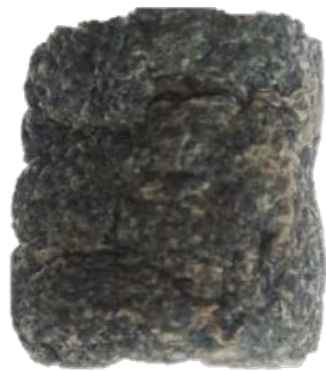

B

Gambar 4. Spons yang dihasilkan dengan penambahan charcoal dengan proses perendaman etanol. A. menggunakan larutan $\mathrm{Na}_{2} \mathrm{CO}_{3}$. B. menggunakan larutan $\mathrm{NaOH}$.

Dari hasil perlakuan pembuatan spons tersebut, kemudian dipilih perlakuan dengan perendaman etanol. Spons glukomannan yang dihasilkan dengan perlakuan perendaman etanol, terjadi perbedaan yang 
signifikan pada penambahan alkali yang berbeda. Perbedaan hasil spons yang berbeda alkali tersebut dapat dilihat pada Tabel 1.

Tabel 1. Karakter Spons pada Alkali yang Berbeda

\begin{tabular}{lclc}
\hline $\begin{array}{c}\text { Alkali yang } \\
\text { Digunakan }\end{array}$ & Tekstur & $\begin{array}{l}\text { Tingkat Kekeringan } \\
\text { Spons }\end{array}$ & Penyusutan \\
\hline $\mathrm{NaOH}$ & Keras & $\begin{array}{l}\text { Sangat Kering baik } \\
\text { bagian luar maupun } \\
\text { dalam }\end{array}$ & $\begin{array}{c}\text { Penyusutan spons dengan } \\
\text { alkali NaOH lebih banyak } \\
\text { dibanding dengan alkali }\end{array}$ \\
& & $\begin{array}{l}\text { Hanya bagian luar } \\
\mathrm{Na}_{2} \mathrm{CO}_{3}\end{array}$ & Lang sangat kering, \\
& & $\begin{array}{c}\mathrm{Na}_{2} \mathrm{CO}_{3} \\
\text { bagian dalam tidak } \\
\text { terlalu kering }\end{array}$ & \\
\hline
\end{tabular}

\subsection{Uji Daya Serap Spons.}

Pengaruh jenis alkali yang digunakan terhadap daya serap spons dapat dilihat pada Gambar 5. Dari Gambar 5. Terlihat bahwa spons glukomannan dengan menggunakan alkali $\mathrm{NaOH}$ memiliki daya serap yang lebih besar dibandingkan dengan spons glukomannan yang menggunakan alkali $\mathrm{Na}_{2} \mathrm{CO}_{3}$.

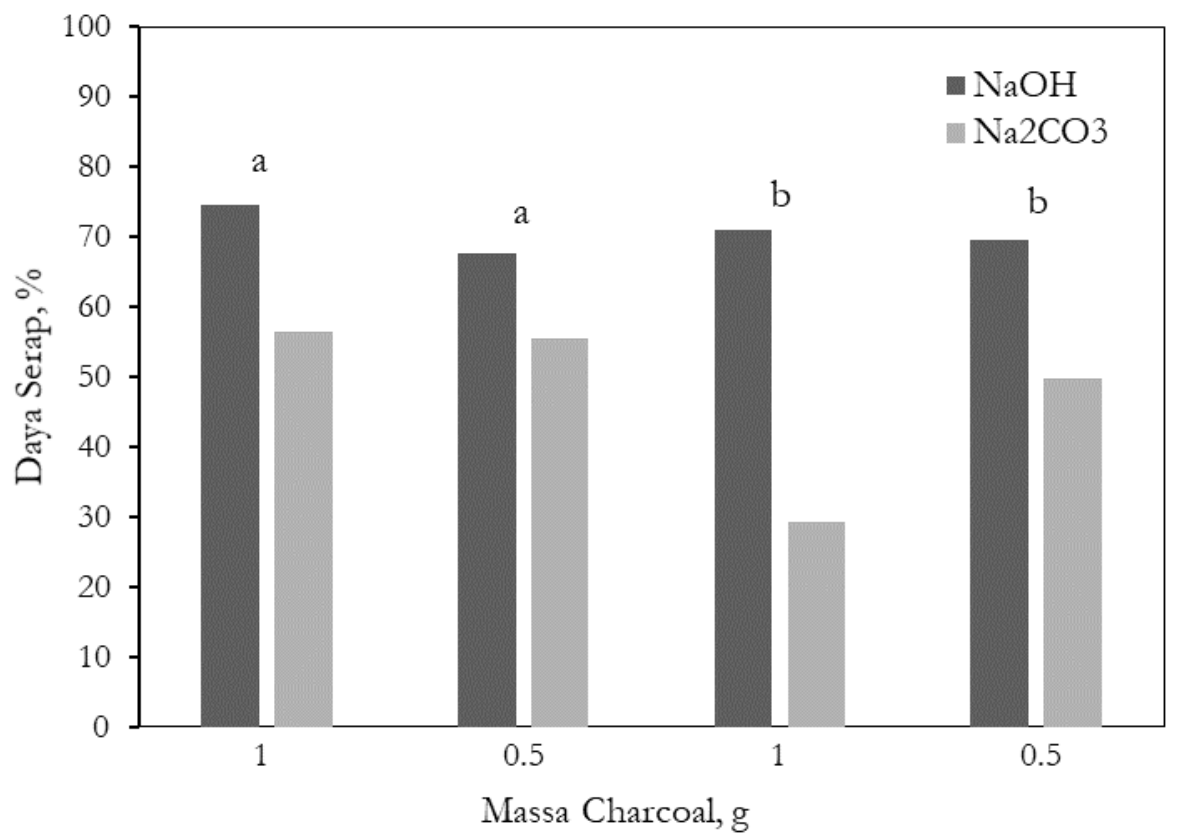

Gambar 5. Persentase daya serap spons pada dua jenis alkali dan berbagai massa charcoal (Ukuran charcoal (a) $-50+60$ mesh, (b) $-60+70$ mesh)

Pengaruh jumlah penambahan charcoal terhadap daya serap spons dapat dilihat pada Gambar 6. Adapun variasi jumlah penambahan charcoal yaitu 1 gram dan 0,5 gram. Dari Gambar 6 dapat disimpulkan bahwa penambahan jumlah charcoal 1 gram cenderung memiliki daya serap spons yang tinggi dibanding dengan penambahan charcoal 0,5 gram. 


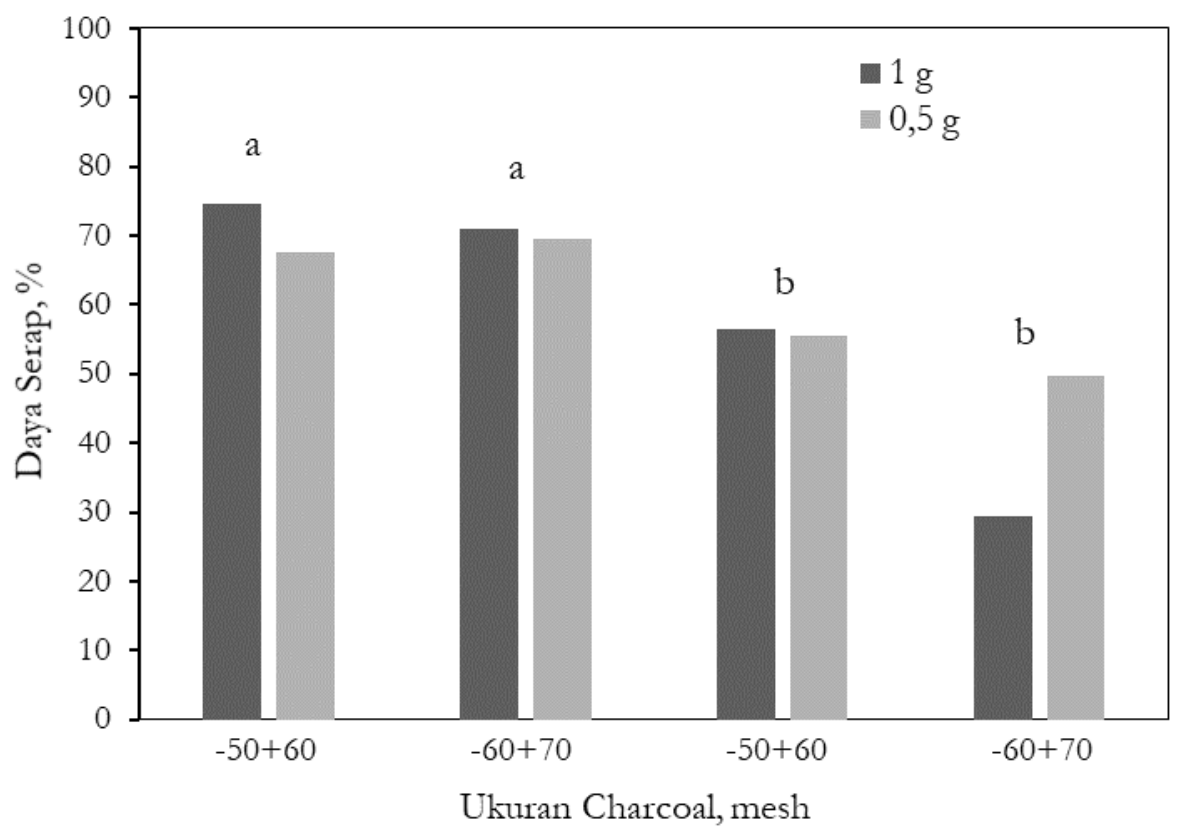

Gambar 6. Persentase daya serap spons pada dua massa charcoal dengan ukuran yang berbeda (Jenis alkali (a) $\mathrm{NaOH}\left(\right.$ b) $\mathrm{Na}_{2} \mathrm{CO}_{3}$ )

Gambar 7 menunjukkan pengaruh ukuran charcoal terhadap daya serap spons glukomanan. Adapun ukuran charcoal yang dipergunakan ada dua yaitu $-50+60$ mesh dan $-60+70$ mesh. Dari Gambar 7 dapat disimpulkan bahwa charcoal ukuran charcoal $-50+60$ mesh cenderung mengakibatkan daya serap spons yang lebih tinggi dibanding dengan charcoal $-60+70$ mesh.

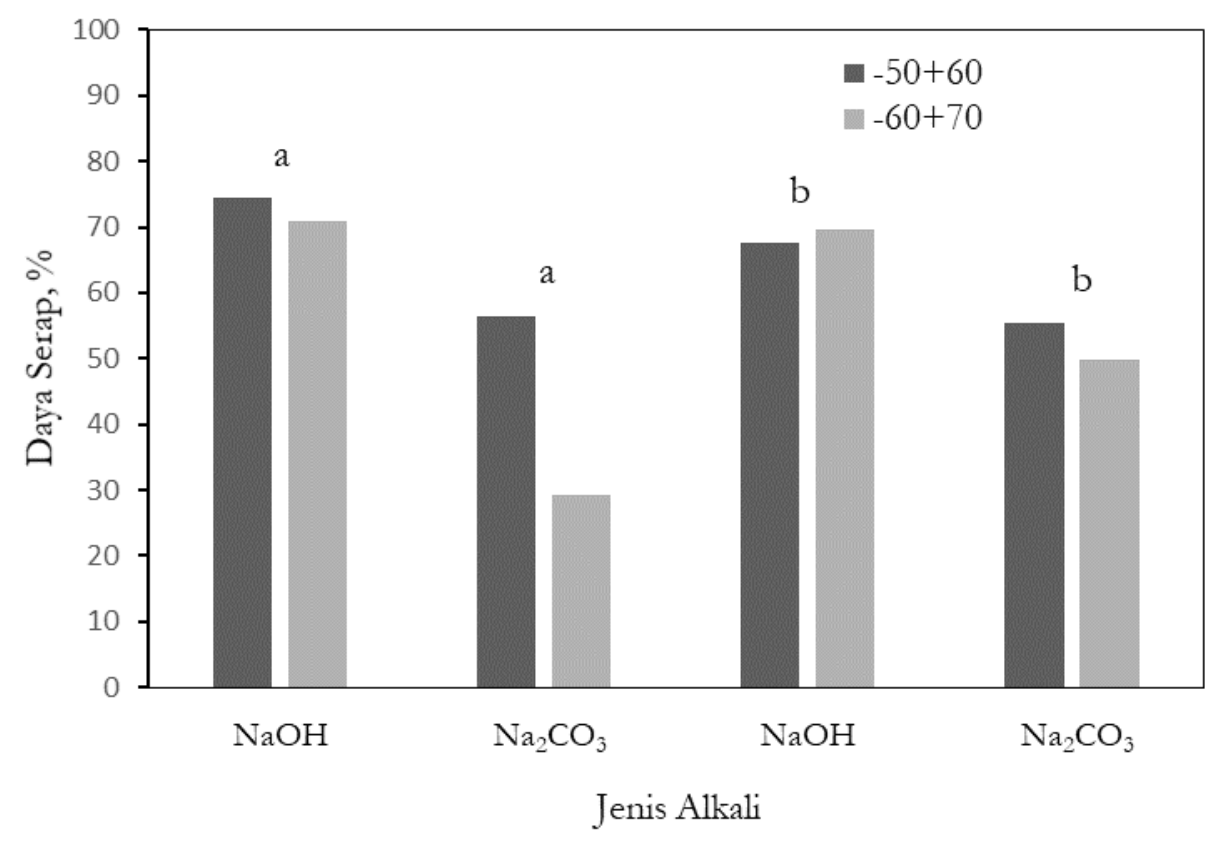

Gambar 7. Persentase daya serap spons pada dua ukuran charcoal dengan jenis alkali yang berbeda. (Jumlah charcoal (a) $1 \mathrm{~g}$ (b) $0,5 \mathrm{~g}$ ).

\subsection{Uji ekspansi spons.}


Pengaruh jenis alkali yang digunakan terhadap presentase penambahan panjang pada spons basah dapat dilihat pada Gambar 8.

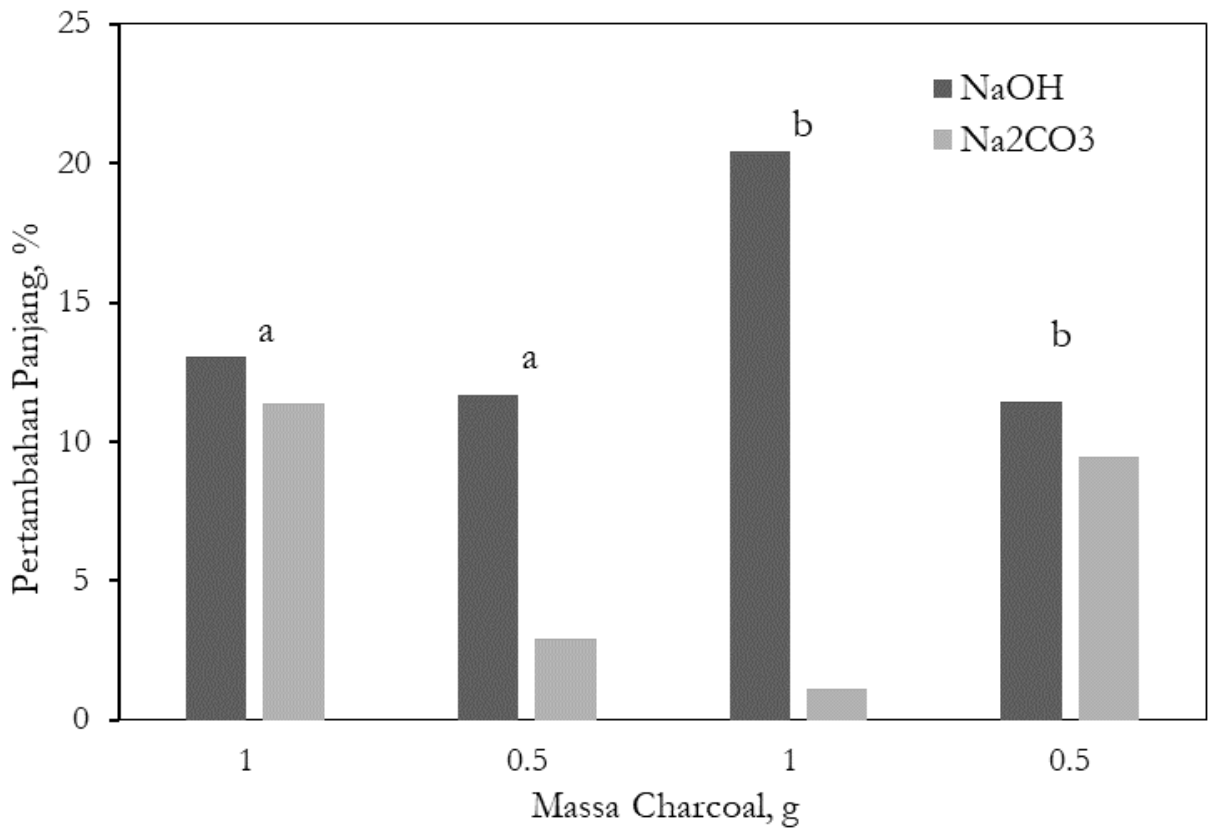

Gambar 8. Ekspansi spons pada dua jenis alkali dengan berbagai massa charcoal (Ukuran charcoal (a) $-50+60$ mesh, (b) $-60+70$ mesh)

Pada Gambar 8 terlihat bahwa spons glukomannan dengan menggunkan $\mathrm{NaOH}$ mempunyai penambahan panjang yang lebih besar dibandingkan dengan spons yang menggunakan $\mathrm{Na}_{2} \mathrm{CO}_{3}$. Ternyata, meski spons dengan $\mathrm{NaOH}$ mempunyai tekstur yang lebih keras, spons ini mempunyai daya ekspansi yang lebih besar. Pengaruh massa charcoal yang ditambahkan terhadap ekspansi spons dapat dilihat pada Gambar 9. Dari Gambar 9 dapat dilihat bahwa penambahan massa charcoal sejumlah $1 \mathrm{~g}$ mengakibatkan spons mempunyai ekspansi yang lebih besar dibandingkan dengan penambahan sejumlah $0,5 \mathrm{~g}$.

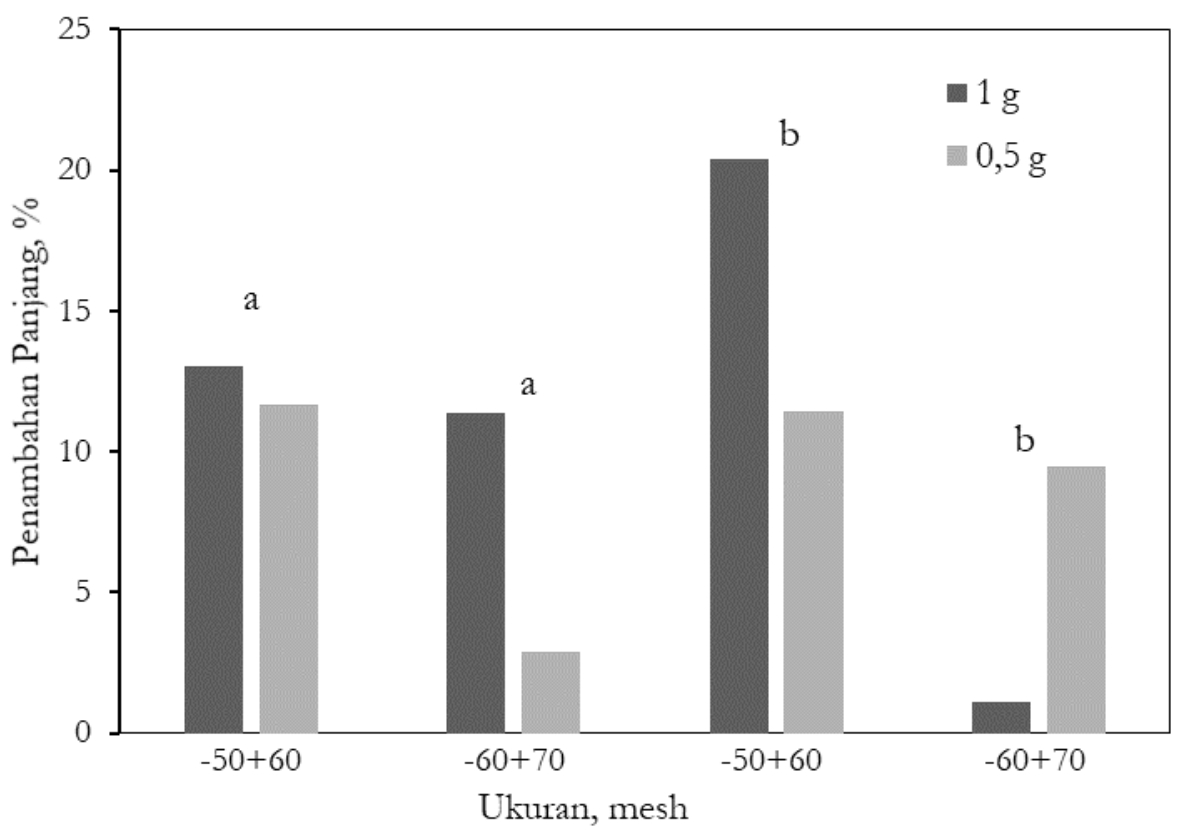

Gambar 9. Ekspansi spons pada massa dan ukuran charcoal yang berbeda (Jenis Alkali (a) $\mathrm{NaOH}$ (b)

$$
\mathrm{Na}_{2} \mathrm{CO}_{3} \text { ) }
$$


Gambar 10 menunjukkan pengaruh ukuran charcoal terhadap daya ekspansi spons. Dari Gambar 10 dapat dikatakan bahwa ukuran charcoal tidak berpengaruh terhadap daya ekspansi spons.

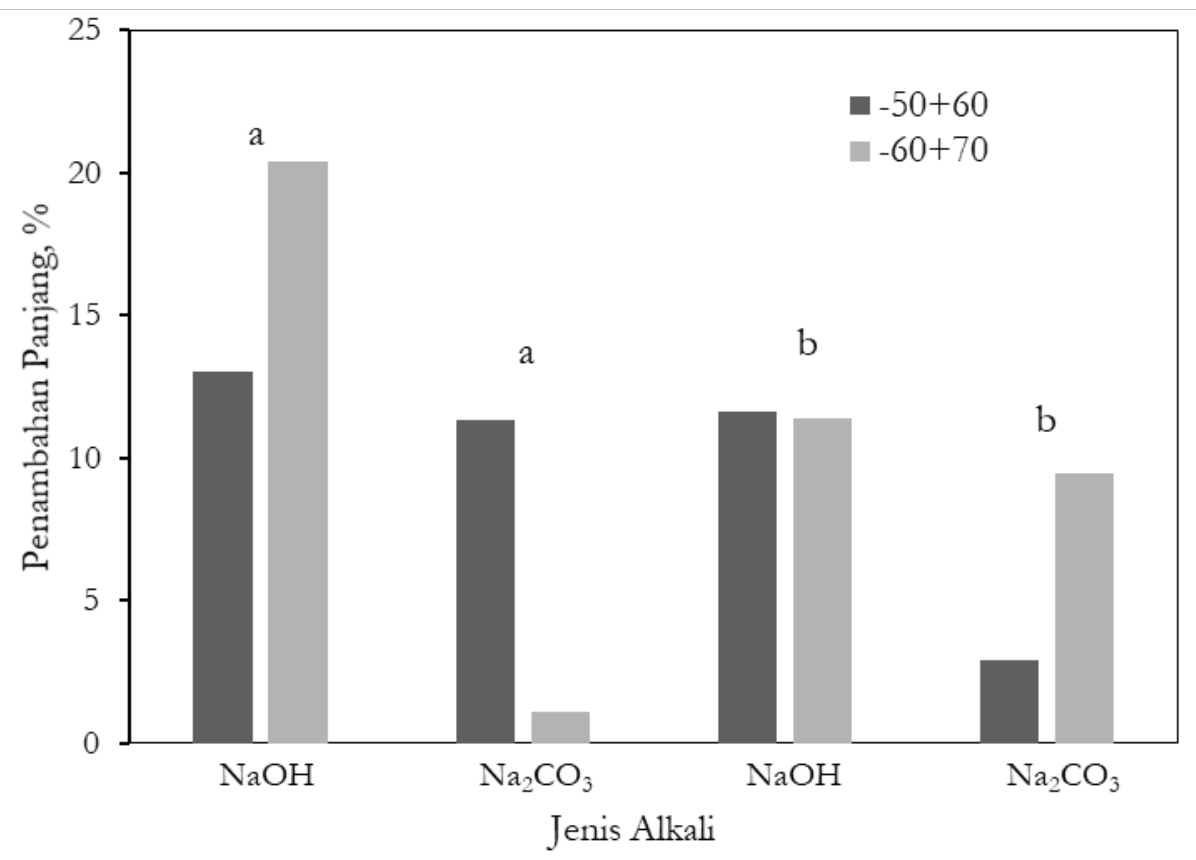

Gambar 10. Ekspansi spons pada dua ukuran charcoal dengan jenis alkali yang berbeda. (Jumlah charcoal (a) $1 \mathrm{~g}$ (b) $0,5 \mathrm{~g}$ ).

\subsection{Rongga spons}

Pengukuran rongga spons dilakukan dengan membuat foto mikroskop dari irisan spons dengan menggunakan Dinolite. Dengan menggunakan software ImageJ maka dapat dihitung diameter rongga spons. Hasil pengukuran rongga pada berbagai variabel yang mempengaruhinya dapat dilihat pada Gambar 11 sampai dengan Gambar 13. Rongga dari spons glukomanan dengan penambahan charcoal mempunyai ukuran diameter antara $0,1 \mathrm{~mm}$ sampai $0,25 \mathrm{~mm}$.

Gambar 10 menunjukkan pengaruh jenis alkali terhadap ukuran rongga spons. Dari gambar dapat dilihat bahwa alkali $\mathrm{NaOH}$ membuat spons mempuyai ukuran pori yang lebih besar dibandingkan dengan ukuran pori spons dengan $\mathrm{Na}_{2} \mathrm{CO}_{3}$. Nampaknya $\mathrm{NaOH}$ yang merupakan alkali yang lebih kuat dibandingkan dengan $\mathrm{Na}_{2} \mathrm{CO}_{3}$ mengakibatkan ikatan yang terbentuk di dalam gel basah juga lebih kuat. Hal ini mengakibatkan rongga yang dibentuk mempubyaj ukuran yang lebih kecil. 


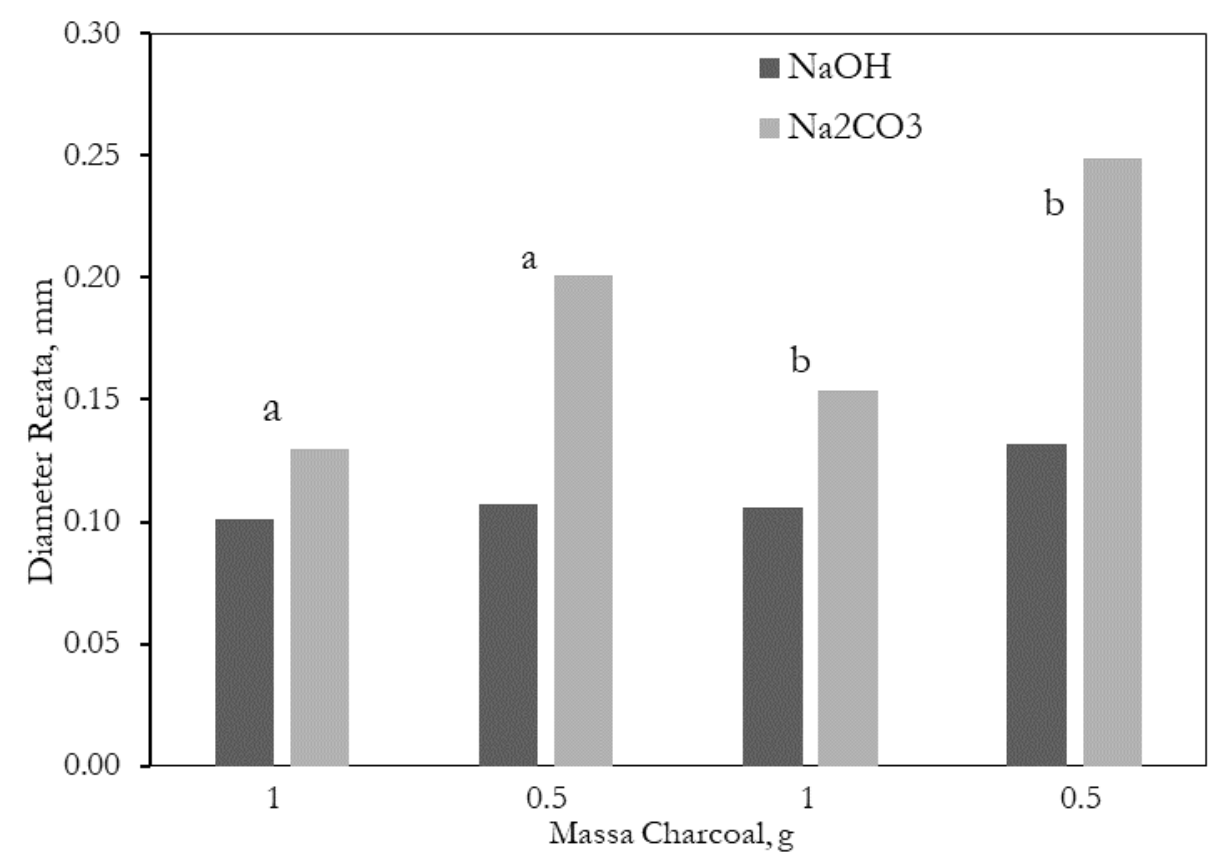

Gambar 11. Pengaruh jenis alkali yang digunakan terhadap diameter rata - rata rongga spons pada berbagai massa charcoal (Ukuran charcoal (a) $-50+60$ mesh (b) $-60+70$ mesh).

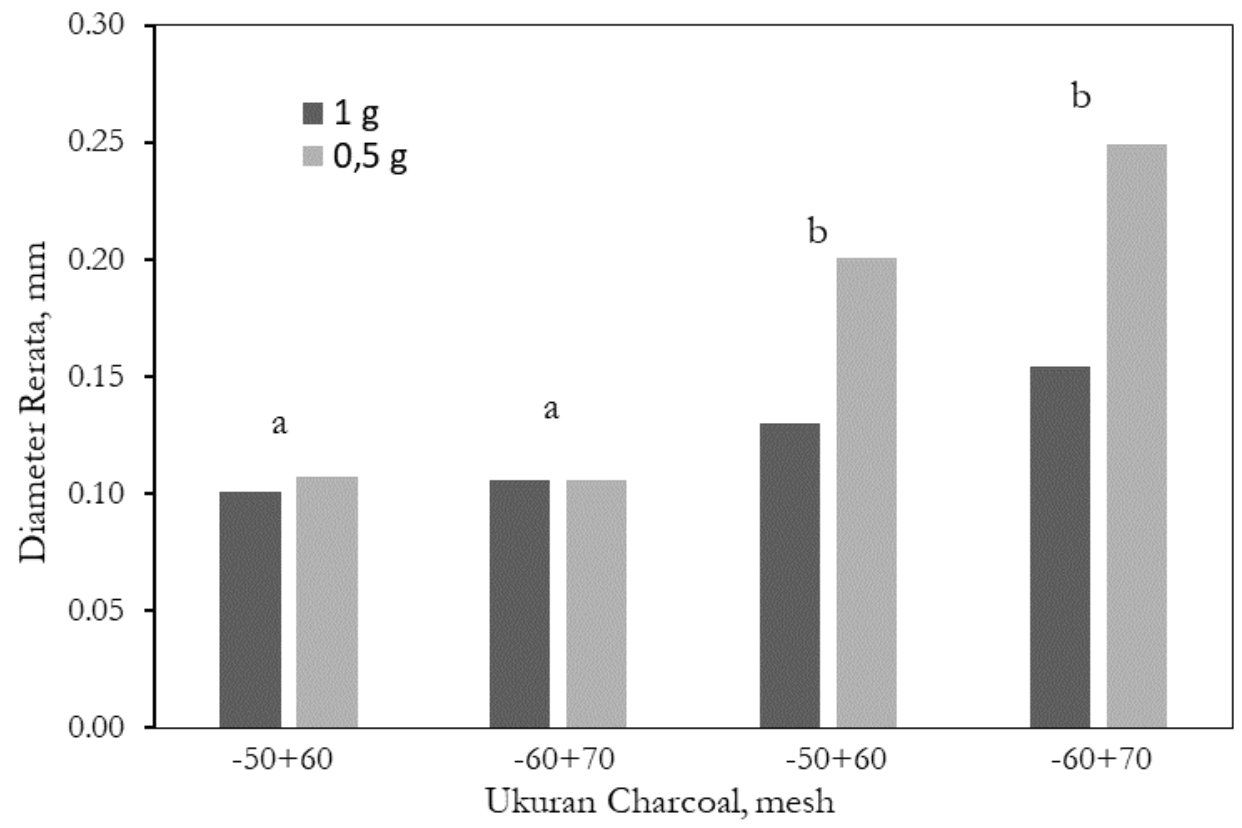

Gambar 12. Pengaruh massa charcoal terhadap diameter rata - rata rongga spons pada berbagai ukuran charcoal (Jenis alkali (a) $\mathrm{NaOH}$ (b) $\mathrm{Na}_{2} \mathrm{CO}_{3}$ ). 


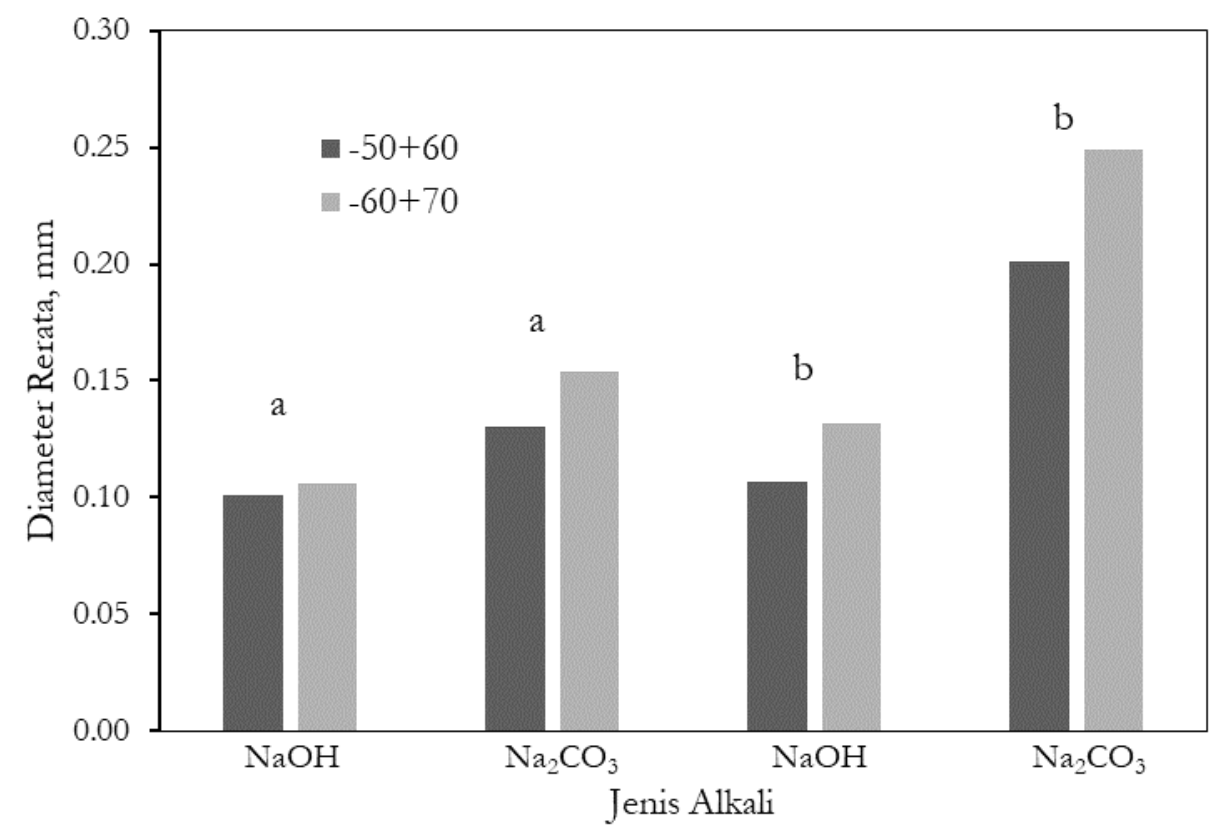

Gambar 13. Pengaruh ukuran charcoal terbadap diameter rata - rata rongga spons pada 2 jenis alkali (Massa charcoal (a) $\lg$ (b) $0,5 \mathrm{~g}$ )

Gambar 12 menunjukkan pengaruh massa spons terhadap ukuran diameter rongga spons. Spons yang dibuat dengan penambahan $0,5 \mathrm{~g}$ charcoal mempuyai rongga yang lebih besar dibandingkan dengan spons dengan penambahan $1 \mathrm{~g}$ charcoal. Jumlah charcoal yang lebih sedikit mengakibatkan udara dapat terdispersikan dengan lebih baik dan ruang yang terbentuk oleh disperse udara mempunyai volum yang lebih besar.

Gambar 13 menujuukan pengaruh ukuran charcoal terhadap diameter rongga spons. Ukuran charcoal yang lebih kecil membuat spons mempunyai ukuran yang lebih besar. Udara yang dimasukkan selama proses pengadukan larutan glukomanan menempati ruang dengan volume yang lebih besar saat ukuran charcoal lebih kecil.

\subsection{Nilai Iod teradsorpsi (Bilangan Iod).}

Bilangan iod menunjukkan besarnya daya serap spons terhadap suatu larutan berwarna. Pengujian terhadap bilangan iod banyak dilakukan terhdap karbon aktif. Semakin besar nilai bilangan iod maka kemampuan adsorpsi semakin besar. Pengujian bilangan iod dilakukan untuk melihat kemampuan spons dalam menyerap kotoran.

Gambar 14 menunjukkan pengaruh jenis alkali terhadap bilangan iod pada spons glukomanan pada berbagai massa dan ukuran charcoal. Dari Gambar 14 terlihat bahwa spons yang dibuat dengan menggunakan alkali $\mathrm{Na}_{2} \mathrm{CO}_{3}$ mempunyai bilangan iod yang lebih besar. 


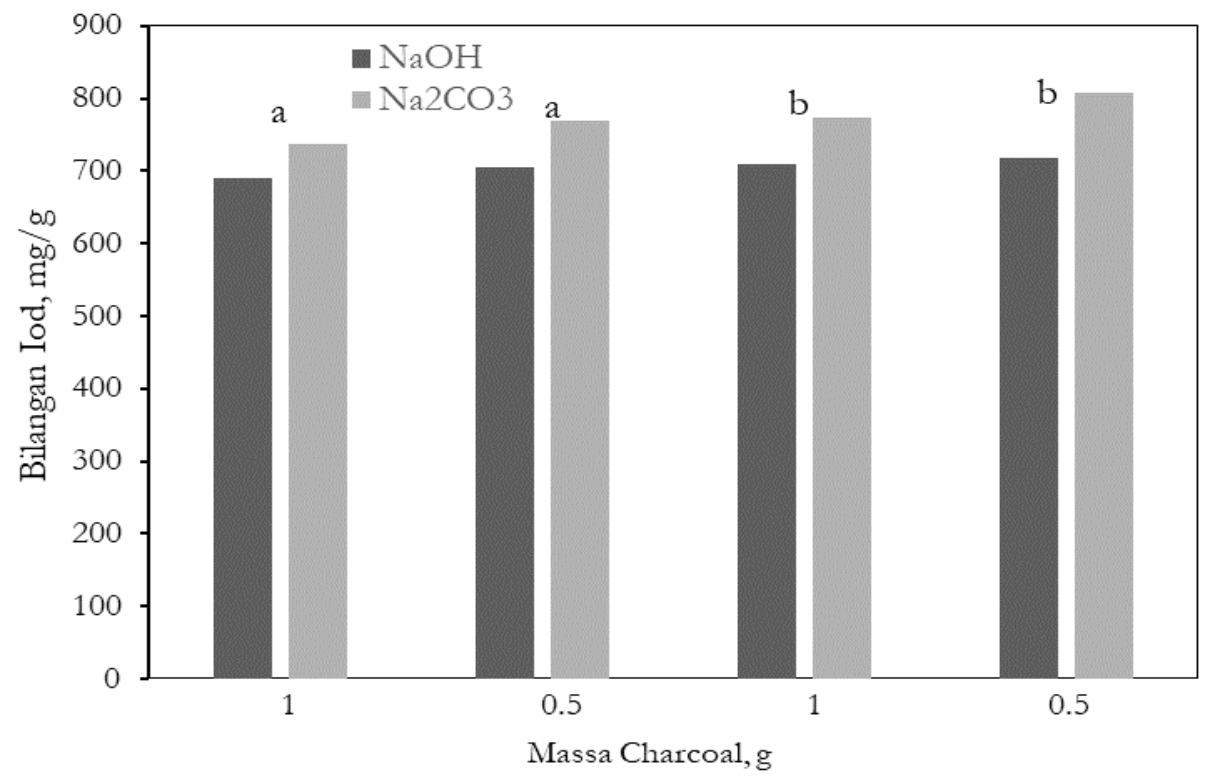

Gambar 14. Pengaruh jenis alkali yang digunakan terhadap bilangan iod pada berbagai massa charcoal (Ukuran charcoal (a) -50+60 mesh (b) -60+70 mesh).

Pengaruh jumlah charcoal yang ditambahkan terhadap bilangan iod dapat dilihat pada Gambar 15. Tidak seperti yang diharapkan, Gambar 15 menunjukkan bahwa penambahan 0,5 g charcoal mengakibatkan bilangan iod yang lebih tinggi. Charcoal sendiri merupakan suatu adsorben, sehingga jumlah charcoal yang lebih banyak mengakibatkan daya serap yang lebih tinggi.

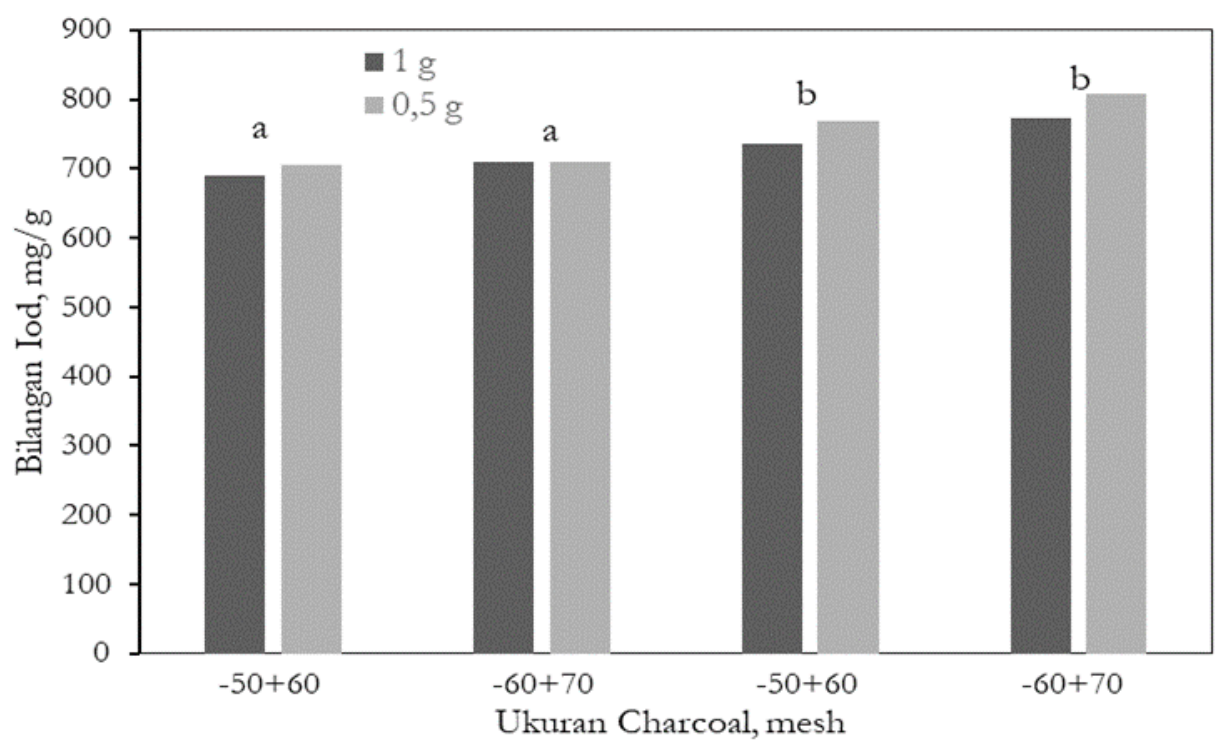

Gambar 15. Pengaruh massa charcoal yang digunakan terhadap bilangan iod pada berbagai ukuran charcoal (Jenis alkali (a) $\mathrm{NaOH}$ (b) $\mathrm{Na}_{2} \mathrm{CO}_{3}$ ). 


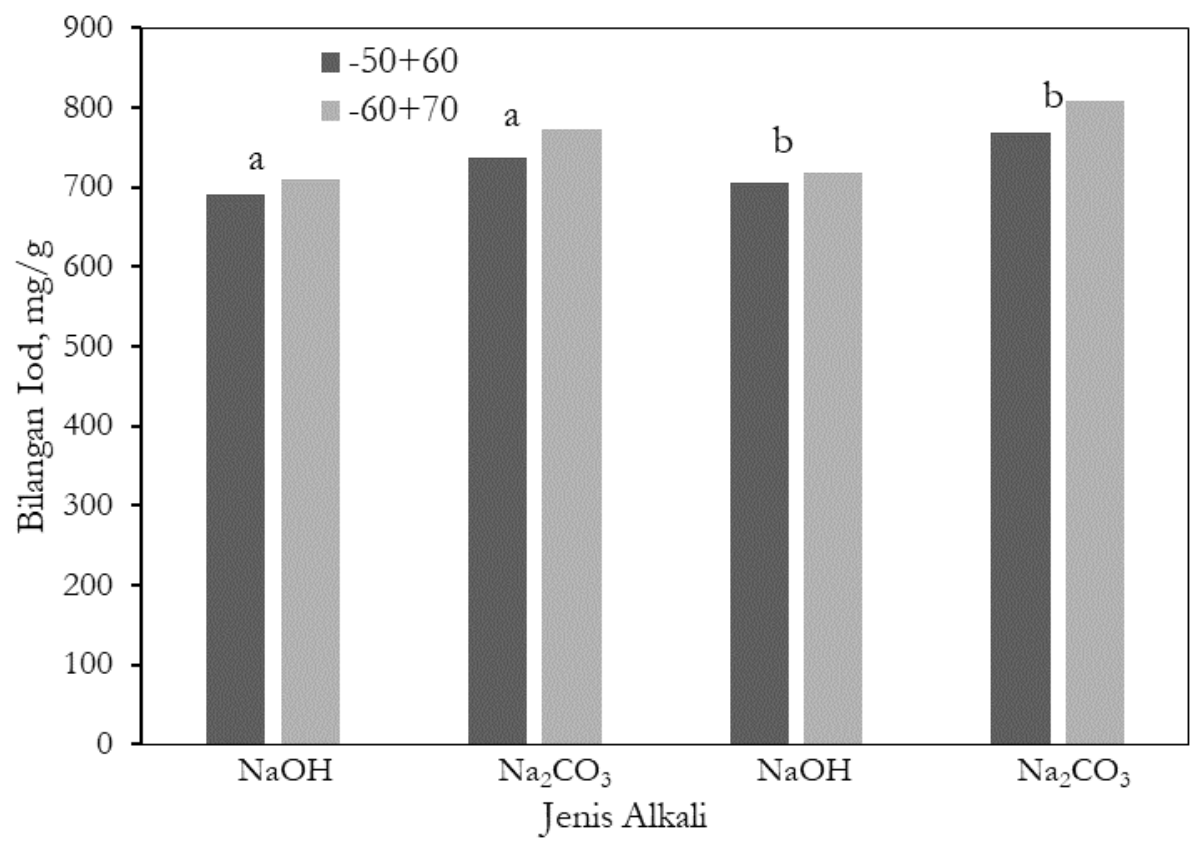

Gambar 16. Pengaruh ukuran charcoal yang digunakan terhadap bilangan iod pada berbagai massa jenis alkali (Massa charcoal (a) $1 \mathrm{~g}$ (b) 0,5 g)

Pengaruh ukuran charcoal terhadap bilangan iod dari spons ditunjukkan oleh Gambar 16. Terlihat bahwa dengan ukuran charcoal yang lebih kecil, bilangan iod dari spons lebih besar. Ukuran charcoal yang lebih kecil menyediakan luas permukaan yang lebih besar, sehingga tingkat penyerapan menjadi lebih besar.

\section{Kesimpulan}

Dari hasil percobaan dapat disimpulkan bahwa spons glukomanan dapat dihasilkan dengan dengan menggunakan alkali $\mathrm{NaOH}$ dan $\mathrm{Na}_{2} \mathrm{CO}_{3}$. Spons yang dihasilkan mempunyai rongga dengan ukuran antara $0,1 \mathrm{~mm}$ sampai $0,25 \mathrm{~mm}$. Spons dengan daya serap air dan daya ekspansi tinggi diperoleh pada penambahan larutan $\mathrm{NaOH}$, massa charcoal yang ditambahkan sebesar $1 \mathrm{~g}$ serta ukuran charcoal $+50-60$ mesh. Sedangkan spons yang dihasilkan apabila menggunakan alkali berupa $\mathrm{Na}_{2} \mathrm{CO}_{3}$ dengan massa charcoal yang ditambahkan sebesar 0,5gram serta ukuran charcoal $+60-70$ mesh memiliki diameter rata-rata rongga spons dan nilai iod teradsorpsi yang tinggi.

\section{Referensi}

[1] A. Svagan, Bio-inspired polysaccharide nanocomposites and foams, Thesis. KTH, School of Chemical Science and Engineering (CHE), Fibre and Polymer Technology, 2006.

[2] B. E. Obi, Fundamentals of Polymeric Foams and Classification of Foam Types in Polymeric Foams Structure-Property-Performance, 93-129, 2018

[3] D.B. Eagles, dkk., , Method of Producing Polysaccharide Foams, US Patent No: 5840777, United States of America, 1998

[4] Glikcsman, , Food hydrocolloids, Vol. I, Florida: CRC Press Boca Raton. 1983

[5] K. Kimura, Method Of Producing Glucomannan Sponge, Appl. No: 196.727, Japan, Shimizu Chemical Corporation, 1994,

[6] S. Koswara, , Teknologi Pengolahan Umbi - umbian Bagian 2: Pengolahan Umbi Porang, Bogor, USAID, 2013

[7] X. Luo, H. Pan, L. Xiaoyan., , The Mechanism of Sodium Hydroxide Solution Promoting the Gelation of Konjac, Sichuan, 2013 
[8] S. Triyanto, T.N. Prakoso dan Fadilah, Studi pembuatan spons dari tepung porang kuning (Amorphophallus muelleri Blume), Prosiding Seminar Nasional Teknik Kimia EcoSmart 2018, 2018.

[9] Mahayasih, P. G. M. W., T. Handoyo, dan M. A. Hidayat, Uji Aktivitas Protein Larut Air Umbi Porang (Amorphallus muelerri Blume) terhada Escherchia coli dan Staphylococcus aureus, Pustaka Kesehatan ISSN 2335-178X, 2013

[10] J. Piret, A. Desormeaux, M.G. Bergeron. "Sodium lauryl sulfate, a microbicide effective against enveloped and nonenveloped viruses.". Curr Drug Targets 3 (1): 17-30. doi:10.2174/1389450023348037. PMID 11899262. 2002

[11] K Prasetya,., N. Nurgirisia, dan Fadilah., Sintesis Hidrogel Dari Glukomannan Umbi Porang. (Amorphophallus Muelleri Blume) Dengan Metode Deasetilasi Sebagai Super Absorben Polimer, Prosiding Senatek, ISBN 978-602-14355-0-2. 2015

[12] Widjanarko, S. B. dan J. Megawati, 2015, Analisis Metode Kolorimetri Dan Gravimetri Pengukuran Kadar Glukomanan Pada Konjak (Amorphophallus Konjac), Pengukuran Kadar Glukomanan pada Konjak, Vol.3 No 4:1584-1588 